Sonia Kozub-Skalska

Uniwersytet Ekonomiczny w Katowicach

\title{
Mechanizm przestępstw karuzelowych i metody ich ograniczenia
}

\author{
THE MECHANISM OF CAROUSEL OFFENSES \\ AND METHODS OF RESTRICTING THEM
}

\begin{abstract}
Jednym z mechanizmów, który znaczqco przyczynia się do istnienia luki $w$ VAT sq oszustwa podatkowe realizowane $w$ ramach tzw. karuzeli podatkowej. Idea karuzeli podatkowej bazuje na cesze charakterystycznej obecnego systemu VAT, a mianowicie na tym, że należny VAT jest odprowadzany na konta urzędów skarbowych, co do zasady przez sprzedawce towaru. Jednocześnie jednak nabywca, będacy tzw. czynnym podatnikiem VAT, ma prawo do skorzystania z prawa do odliczenia tzw. naliczonego VAT. W przypadku, gdy suma podatku naliczonego przy nabyciu towarów i uslug przewyższa sumę podatku należnego od sprzedaży dokonanej przez podatnika $w$ danym okresie rozliczeniowym, podatnik jest uprawniony do uzyskania bezpośredniego zwrotu VAT. To właśnie wspomniany zwrot VAT jest przestankq, dla której przestępcy podatkowi otwieraja szereg podmiotów i tworza mechanizm karuzeli podatkowych $w$ celu uzyskania korzyści majatkowych z nienależnie otrzymanego zwrotu VAT. Niestety skala tego zjawiska pokazuje, iż zarówno organy skarbowe jak $i$ organy ściganie nie radzq sobie $z$ ograniczaniem tej skali. Celem artykułu jest wskazanie nowych metod ograniczania przestęstw karuzelowych, które przy wspótpracy organów skarbowych, organów ścigania i bieglych sqdowych w znaczqcy sposób pozwolq ograniczyć skale tego zjawiska. Wartościq dodana opracowania jest to, iż nowe metody nie wymagaja zmian legislacyjnych, a więc mogq zostać natychmiast zastosowane $w$ praktyce. $W$ celu przedstawienia zamierzonych celów zastosowano metody badań literaturowych oparte na analizie krajowych $i$ zagranicznych publikacji zwartych $i$ artykułowych oraz danych publicznych udostęnianych przez Ministerstwo Finansów oraz obowiqzujacych aktów prawnych. Zawarte $w$ artykule rozważania maja charakter zarówno teoretyczny jak i praktyczny.
\end{abstract}

Słowa kluczowe: uchylanie się od podatków, kontrole podatkowe, zapobieganie uchylaniu się od podatków, karuzele vat, opinie biegłych sądowych.

\section{Wstęp}

Skala zjawiska przestępstw karuzelowych w ostatnich latach w Polsce znacznie wzrosła. Wyłudzony za pomocą mechanizmów przestępczych podatek VAT stanowi przeważającą część luki w podatkach VAT. Ustawodawca od 1 stycznia 2017 r. wprowadził szereg przepisów mających na celu ograniczenie tego zjawiska. Praktyka pokazuje jednak, iż brak odpowiedniej współpracy między organami podatkowymi i organami ścigania skutkuje małą efektywnością prowadzonych postępowań. W rzeczywistości nie dochodzi do wykrywania faktycznych organizatorów mechanizmów przestępstw karuzelowych. W celu zwiększenia efektywności ograniczania tych przestępstw wystarczy wprowadzić 
metody mające na celu realnie ograniczyć skalę zjawiska. Wprowadzenie nowych metod nie oznacza zmian legislacyjnych a zmiany w zakresie procedur i współpracy między organami podatkowymi, organami ścigania a biegłymi sądowymi $\mathrm{z}$ dziedziny informatyki i ekonomii. Wprowadzenie procedur zbierania i zabezpieczania materiału dowodowego oraz prowadzenie analiz kryminalnych do postępowań dotyczących przestępstw karuzelowych w sposób rzeczywisty ograniczy skalę zjawiska tego rodzaju przestępczości gospodarczej. W artykule zostały poruszone kwestie praktyczne których zastosowanie $\mathrm{w}$ znaczący sposób może przyczynić się do ograniczenia przestępstw karuzelowych jak również do znacznego skrócenia czasu prowadzonych postępowań zarówno podatkowych

jak i karnych.

\section{Charakterystyka przestępstw karuzelowych}

Zjawisko zorganizowanej działalności przestępczej wykorzystującej zasady konstrukcyjne podatku VAT kojarzone jest zazwyczaj z data 1.01 .1993 r., kiedy to zlikwidowano bariery celne pomiędzy poszczególnymi państwami członkowskimi Unii Europejskiej. W efekcie zniesiony został także system poboru podatku (importowego) na granicach państwowych, który stanowił co do zasady podstawę rozliczeń VAT w zakresie wewnątrzwspólnotowego obrotu towarowego. W jego miejsce wprowadzone zostało funkcjonujące do chwili obecnej rozwiązanie bazujące na schemacie opodatkowania w miejscu przeznaczenia (a nie w miejscu pochodzenia) towaru. Jak wskazuje nazwa: „karuzela podatkowa”, czy też „oszustwo karuzelowe” - przestępczy mechanizm, który polega na przepływie towarów pomiędzy państwami członkowskimi Unii Europejskiej w taki sposób, że wracają one do państwa pochodzenia, przy czym karuzela ta ma na celu uchylanie się od opodatkowania i wyłudzanie zwrotu podatku VAT. Poszczególnym transakcjom $\mathrm{w}$ ramach karuzeli nie sposób zarzucić pozorności, gdyż mają one za przedmiot prawdziwe towary, zatem do takiego przestępstwa potrzebny jest prawdziwy towar, najlepiej o małych rozmiarach, znaczącej wartości jednostkowej oraz mało kłopotliwy w kontekście transportu. Mając towar trzeba po prostu stworzyć karuzelę poprzez utworzenie szeregu podmiotów lub wykorzystanie już funkcjonujących tak, aby towar mógł przez te podmioty przepływać. I tak potrzebna jest po pierwsze tzw. spółka wiodąca, której zadaniem jest organizacja kanału dystrybucyjnego na potrzeby przestępczego łańcucha transakcji. $Z$ tego powodu spółka wiodąca zwana jest tez „kanałowa” lub po prostu kanałem dystrybucyjnym. Występuje ona z jednej strony jako dostawca towarów dla tzw. „znikających handlowców”, z drugiej zaś - jako nabywca tych samych towarów zbywanych w ramach tzw. WNT (wewnątrzwspólnotowego nabycia towarów) albo eksportu przez tzw. „brokerów”. Spółka wiodąca czy tez kanałowa ulokowana jest poza granicami państwa, na którego terytorium fizycznie popełnione jest przestępstwo skarbowe, czyli jest poza jurysdykcja podatkową i karna państwa, w którym dochodzi do wyłudzenia VAT-u i zasadniczo spółka wiodąca prawidłowo rozlicza się z tytułu VAT-u i wykonuje obowiązki wynikające z przepisów prawa. Następnie potrzebny jest podmiot, który określa się - jak wspomniano - mianem ,znikającego handlowca”. Jest to stricte podmiot przestępczy zarządzany formalnie przez tzw. „ludzi - słupów” (ang. „strawmen”) bez majątku, potrzebnych tylko do podpisywania wszelkich wymaganych dokumentów (za 
niewielkim wynagrodzeniem). Podmioty nabywające towar od znikającego handlowca nazywane są „buforami”. Nieraz jest ich więcej. „Bufor” prowadzi legalną działalność i wywiązuje się ze zobowiązań podatkowych. Głównym celem przeprowadzenia transakcji krajowych pomiędzy wieloma firmami buforowymi jest utrudnienie ewentualnego postępowania podatkowego i zatarcie powiazań, jakie istnieją pomiędzy znikającym handlowcem, a kolejnym elementem łańcucha zwanym brokerem oraz spółka wiodąca ${ }^{1}$. Typowy lańcuch transakcji $\mathrm{w}$ przestępstwach karuzelowych przedstawia rysunek 1 .

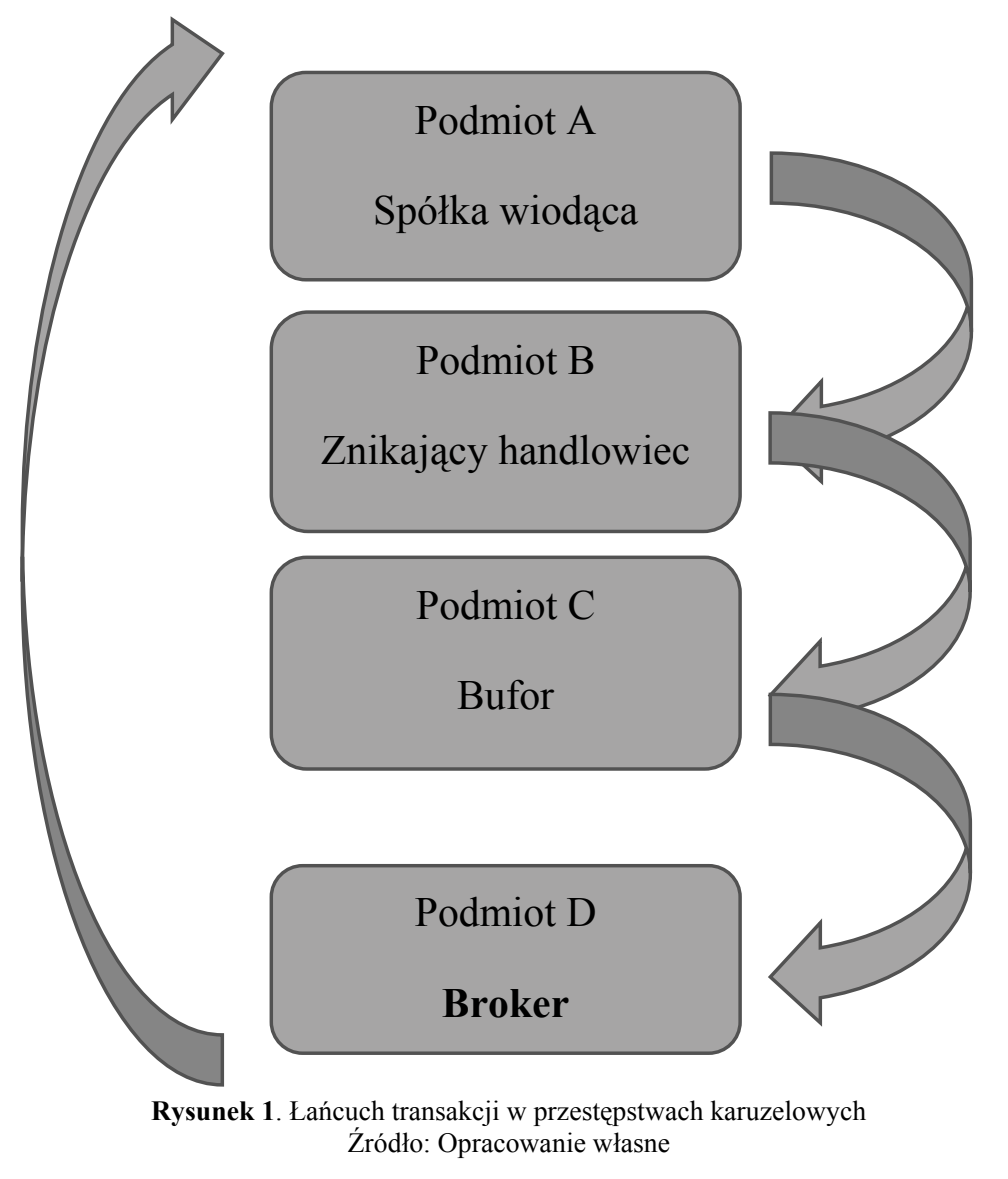

W zwalczaniu nadużyć w przestępczości gospodarczej kluczowe jest przypisanie przez organy skarbowe oraz ścigania poszczególnych ról jakie pełnią $\mathrm{w}$ łańcuchu dostaw podmioty gospodarcze.

\footnotetext{
${ }^{1}$ L. Wilk: Kryminalne aspekty przestępczości podatkowej, Archiwum Kryminologii, TOM XXXI/2009, Warszawa 2009, s. 214-216.
} 
Znikający handlowiec (missing trader) - Definicja „missing trader” znajduje się w art.2 Rozporządzenia Komisji Europejskiej (WE) Nr 1925/2004, zgodnie z którym znikający podatnik oznacza podmiot zarejestrowany na potrzeby podatku VAT, potencjalnie prowadzący działalność z zamiarem dokonania oszustwa podatkowego wobec VAT, który nabywa lub utrzymuje, że nabywa towary lub usługi bez zapłaty podatku VAT, a następnie dokonuje dostawy tych towarów lub usług $\mathrm{z}$ naliczeniem kwot podatku VAT ale nie odprowadza kwot podatku należnego do odpowiednich jednostek władz państwowych ${ }^{2}$.

Bufor - Bufor stanowi rodzaj podmiotu umiejscowionego w transakcjach karuzelowych między znikającym handlowcem, a brokerem. Z reguły występuje cały szereg tzw. buforów, które są generalnie podmiotami skrupulatnie wypełniającymi wszelkie formalne obowiązki związane $\mathrm{z}$ rozliczeniami VAT. Realizują tym samym funkcje przewidzianą dla nich przez organizatora oszukańczej praktyki przez sama obecność pomiędzy najbardziej wrażliwymi ogniwami przestępczego łańcucha dostaw ${ }^{3}$. Należy zaznaczyć, iż Bufor jest narażony na to, iż w sposób nieświadomy zostanie wciągnięty w mechanizm przestępstwa karuzelowego.

Broker - Broker występuje $\mathrm{w}$ transakcjach jako ostatnie ogniwo łańcucha dostaw $\mathrm{W}$ państwie, do którego towary zostały sprowadzone przez znikającego handlowca. Możliwe są przypadki, w których broker, będący co do zasady poważaną firmą o ustabilizowanej pozycji na rynku, odsprzeda zakupione od buforów towary na rynku krajowym, pośrednio czerpiąc korzyść $z$ oszukańczego schematu za pośrednictwem nierynkowo niskich cen sprzedaży stosowanych przez poprzednie ogniwa łańcucha ${ }^{4}$.

Przedsiębiorstwo wiodące (ang. Conduit company) - Organizator przestępstwa karuzelowego, który jest $\mathrm{z}$ reguły najtrudniejszy do wykrycia, gdyż w zasadzie jego rozliczenie podatkowe zasadniczo nie budzi większych podejrzeń. Przeważnie karuzela, czyli obrót towarem, rozpoczyna się i kończy na tym podmiocie 5 .

Poniżej na rysunku 2 został zaprezentowany typowy schemat karuzeli VAT.

\footnotetext{
${ }^{2}$ Rozporządzenie Komisji (WE) nr 1925/2004 z dnia 29 października 2004 r. ustanawiające szczegółowe zasady wykonywania niektórych przepisów rozporządzenia Rady (WE) nr 1798/2003 w sprawie współpracy administracyjnej w dziedzinie podatku od wartości dodanej (Dz. U. UE. L. z 2004 r. Nr 331, str. 13 z późn. $\mathrm{zm}$.).

${ }^{3}$ Kancelaria Prezesa Rady Ministrów. Materiały szkoleniowe z tematu pn. Transakcje wewnątrzwspólnotowe ze szczególnym uwzględnieniem transakcji trójstronnych i łańcuchowych oraz identyfikacja oszustw karuzelowych w handlu wewnątrzwspólnotowym. Warszawa, s. 91.

${ }^{4}$ Ibidem

${ }^{5}$ Ibidem
} 


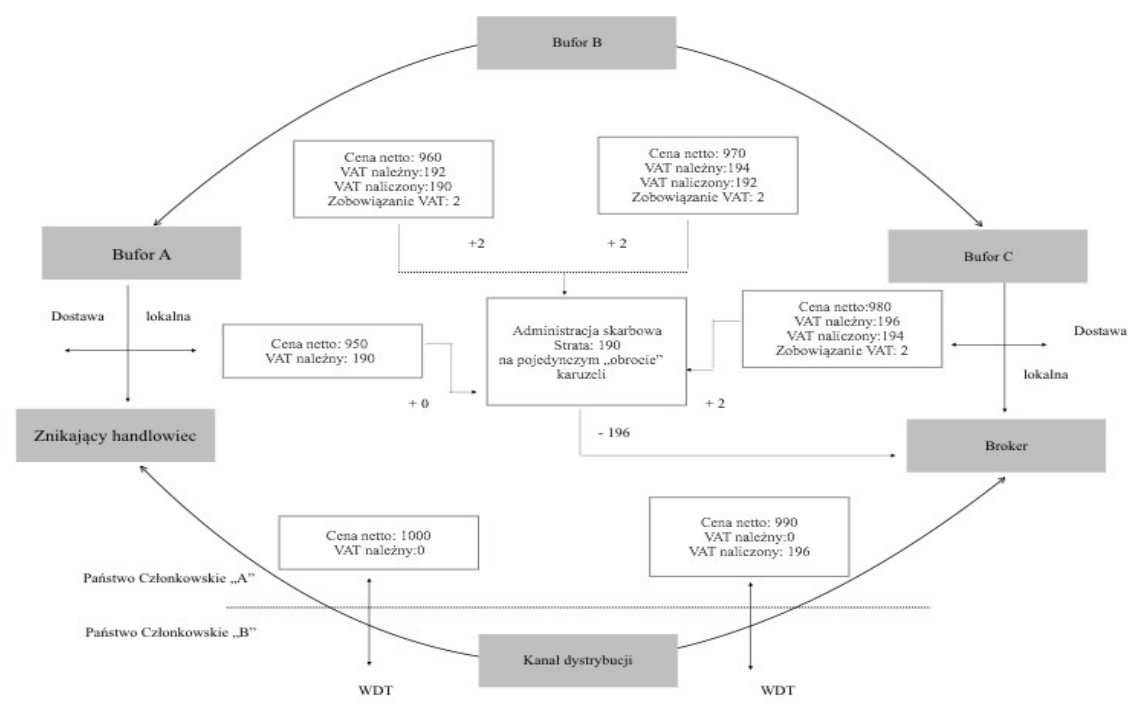

Rysunek 2. Schemat karuzeli VAT

Źródło: Przegląd Podatkowy [1/2007, s. 21]

Konkludując powyższe rozważania należy zwrócić szczególną uwagę na konieczność przypisywania konkretnych ról poszczególnym uczestnikom przestępstw karuzelowych, ponieważ tylko takie działanie pozwoli otworzyć schemat karuzeli zawarty w rysunku 2 .

\section{Współpraca organów skarbowych i organów ściągania na gruncie przestępstw karuzelowych}

Pytanie o rolę organów podatkowych, a zwłaszcza organów kontroli skarbowej, w zwalczaniu procederu przestępnego nadużycia mechanizmów podatków VAT i akcyzowego bywa postrzegane w kategorii na jakich organach - karnych czy skarbowych ma spoczywać ciężar walki $\mathrm{z}$ tego rodzaju zachowaniami sprawczymi. Argumentem za pozostawieniem tej sfery głównie organom skarbowym jest to, że sprawcy wykorzystują tu mechanizmy prawa podatkowego, argumentem zaś, że sprawy te powinny stanowić domenę organów ścigania, jest zorganizowany charakter tej przestępczości i przestępstwa jej towarzyszące (fałszerstwa dokumentów, grupa przestępcza, pranie pieniędzy). Paradoksalnie przedstawiciele zarówno praktyki, jak i teorii prawa podatkowego patrzą na problem właśnie przez taki pryzmat ${ }^{6}$. W ocenie autora konieczna jest jednoczesna współpraca, gdyż praktyka pokazuje, że same organy

${ }^{6}$ J. Duży: Rozdział I Etiologia zorganizowanej przestępczości nadużywającej mechanizmów podatkowych. W: Zorganizowana przestępczość podatkowa w Polsce. Zwalczanie przestępczego nadużycia mechanizmów podatków VAT i akcyzowego. LEX, 2013, s.128. 
podatkowe nie gromadzą materiału dowodowego w sposób wyczerpujący dla postępowania karnego.

Analizując zaś informację o wynikach kontroli opublikowaną przez Najwyższą Izbę Kontroli w dokumencie „Przeciwdziałanie wprowadzaniu do obrotu gospodarczego faktur dokumentujących czynności fikcyjne" z dnia 23 marca 2016 r. wynika, iż dotychczasowe regulacje prawne oraz działania okazały się niewystarczające i nie pozwalają na skuteczne zabezpieczenie interesów Skarbu Państwa ${ }^{7}$. Raport wskazuje, iż konieczne jest zintensyfikowanie współpracy między służbami podległymi Ministrowi Finansów oraz z prokuratura i Policją oraz skoncentrowanie działań podległych służb na wykrywaniu organizatorów procederu wyłudzania podatku zamiast na firmach "słupach". Wnioski te w zasadzie oddają skalę problemu, ponieważ z praktyki wynika, iż ograny podatkowe, które są pierwszym „ogniwem” zbierającym i zabezpieczającym materiał dowodowy koncentrują się na wydaniu decyzji na tzw. słupy $\mathrm{w}$ ogóle pomijając próbę ustalenia organizatora procederu. Wynika to głównie z faktu, iż w wielu postępowaniach podatkowych nie dochodzi do zbierania i oceny materiału dowodowego, a jego gromadzenie ogranicza się do włączenia materiałów dowodowych zgromadzonych $\mathrm{w}$ innym podstępowaniu podatkowym. Zgodnie $\mathrm{z}$ art. $180 \S 1$ ustawy $\mathrm{z}$ dnia 29 sierpnia 1997 r. - Ordynacja podatkowa - jako dowód należy dopuścić wszystko, co może przyczynić się do wyjaśnienia sprawy, a nie jest sprzeczne z prawem. Z kolei art. 181 o.p. zawiera przykładowe wyliczenie środków dowodowych, podając, iż dowodami w postępowaniu podatkowym mogą być w szczególności ksiegi podatkowe, deklaracje złożone przez stronę, zeznania świadków, opinie biegłych, materiały i informacje zebrane $\mathrm{w}$ wyniku oględzin, informacje podatkowe oraz inne dokumenty zgromadzone w toku czynności sprawdzających lub kontroli podatkowej ${ }^{8}$. W efekcie prowadzi to do sytuacji, w której organ podatkowy wydaje decyzje tylko w oparciu o protokoły kontroli wydane dla innych podmiotów, uzasadniając to, iż podatnik nie dokonał odpowiedniej staranności w celu sprawdzenia swojego kontrahenta. Działania te są sprzeczne z tezami Postanowienia TSUE z 6 lutego 2014 r. C-33/13 (Marcin Jagiełło przeciwko DIS w Lodzi): 33. „W razie uznania przez organy podatkowe w zwiqzku z przestęstwem lub nieprawidłowościami popetnionymi przez wystawce faktury, że transakcja zafakturowana i powoływana jako podstawa prawa do odliczenia nie została rzeczywiście zrealizowana, odmowa prawa do odliczenia wymaga wykazania przez te organy na podstawie obiektywnych przestanek - bez wymagania od odbiorcy faktury podejmowania czynności sprawdzajacych, które nie sq jego zadaniem - iż odbiorca ten wiedziat lub powinien byt wiedzieć, że wskazana transakcja wiaże się z przestępstwem w dziedzinie podatku VAT. ${ }^{\text {", }}$

Postanowienie TSUE z 6 lutego 2014 r. C-33/13 (Marcin Jagiełło przeciwko DIS w Łodzi): 36. „Niezgodne z zasadami funkcjonowania prawa do odliczenia

\footnotetext{
${ }^{7}$ Informację o wynikach kontroli, Przeciwdziałanie wprowadzaniu do obrotu gospodarczego faktur dokumentujących czynności fikcyjne, Nr ewid. 24/2016/P/15/011/KBF, NIK, Warszawa 2016, s. 13.

${ }^{8}$ Ł. Matusiakiewicz: Zastosowanie dowodów z innych postępowań w postępowaniu podatkowym [online]. Publikacje Elektroniczne ABC, 2017-01-02 15:54 [dostęp: 2017-01-26 13:21]. Dostępny w Internecie: https://sip.lex.pl/\#/publikacja/469884042.

${ }^{9}$ Postanowienie Trybunału Sprawiedliwości z dnia 6 lutego 2014 r. C-33/13, Prawo do odliczenia w przypadku faktury wystawionej przez spółkę działającą jako firmant.
} 
przewidzianymi wszóstej dyrektywie jest sankcjonowanie odmowa możliwości skorzystania z tego prawa podatnika, który nie wiedziat i nie mógt wiedzieć, że w ramach danej transakcji dostawca dopuścit się przestępstwa lub że inna transakcja w tańcuchu dostaw, dokonana przed transakcja przeprowadzona przez owego podatnika lub po niej, miała miejsce z naruszeniem przepisów o podatku VAT.".

Organy podatkowe więc korzystając $\mathrm{z}$ możliwości wydawania decyzji $\mathrm{w}$ oparciu o materiał zgromadzony $\mathrm{w}$ innym postepowaniu sami nie gromadzą i nie zabezpieczają materiału dowodowego lub robią to w ograniczonym zakresie. Sytuacja ta jest bardzo niekorzystna dla organów takich jak policja czy prokuratura, ponieważ w przypadku postepowań dotyczących karuzeli VAT okazuje się, iż zanim sprawa znajdzie się $\mathrm{w}$ kompetencji organów ścigania podmioty gospodarcze dokonały zniszczenia lub ukrycia dokumentacji księgowej. Organy podatkowe stosując w postepowaniach często swego rodzaju uproszczenie polegające na wykazywaniu braku ,staranności” podatnika, w efekcie w ogóle nie próbują stworzyć rzeczywistego schematu przebiegu transakcji. Ponadto w przypadku niedokonanych zwrotów podatków często niejako przerzucają obowiązek udowodnienia uczestnictwa w karuzeli VAT przez podmiot gospodarczy na organy ścigania. Warto tu dodać, iż prokuratura nie ma możliwości postawienia uczestnika karuzeli VAT $\mathrm{w}$ akt oskarżenia, bez przeprowadzenia postępowania i udowodnienia poza wszelką wątpliwość, iż w sposób świadomy i zamierzony uczestniczył on w procederze przestępczym. Warto zaznaczyć, iż przestępstwa tzw. karuzelowe zazwyczaj charakteryzują się zorganizowanym charakterem $\mathrm{w}$ rozumieniu art. 258 Ustawy z dnia 6 czerwca 1997 r. Kodeks karny ${ }^{10}$.

Biorąc pod uwage, iż to właśnie prawidłowe zabezpieczenie materiału dowodowego oraz tworzenie schematu organizacyjnego według którego dochodziło do przestępstw karuzelowych koniecznym jest, aby organy podatkowe już na etapie podejrzenia, iż kontrolowany podmiot jest uczestnikiem mechanizmu karuzeli VAT rozpoczynały współprace $\mathrm{z}$ organami ścigania. Pozwoli to na odpowiednie zgromadzenie materiału dowodowego, który będzie podstawą ewentualnych spraw karnych, ale przede wszystkim metodologia ta pozwoli na tworzenie schematu karuzeli VAT i pociągnięcia do odpowiedzialności wszystkich uczestników karuzeli mających świadomość popełnionego przestępstwa, a nie tylko wystawiania decyzji podatkowych na tak zwanych znikających handlowców, którzy nie posiadają żadnego majątku. Tak wydane decyzję nie mają żadnego pozytywnego skutku dla Budżetu Państwa. Ta nieprawidłowa metodologia przy podejściu do postępowań podatkowych dotyczących przestęstw karuzelowych $\mathrm{w}$ efekcie prowadzi do tego, iż faktyczny organizator pozostaje bezkarny $\mathrm{i}$ w zasadzie natychmiast za pomocą innych znikających handlowców „słupów” tworzy następną Karuzele VAT. Organy ścigania zaś pozostają w swoistej bezsilności, ponieważ nie mając materiału dowodowego ich praca $\mathrm{w}$ celu ustalenia faktycznego schematu przestępstwa karuzelowego $\mathrm{i}$ wyciagnięcie odpowiedzialności od osób będących faktycznymi organizatorami staje się bardzo trudna, a czasami wręcz niemożliwa. Ponadto organy ścigania zmuszone są swoje postępowania opierać głównie na decyzjach organu podatkowego, a to $\mathrm{w}$ sposób oczywisty niepotrzebnie wydłuża prowadzone postępowania. Wynika to z faktu, iż od momentu wydania decyzji przez organ pierwszej instancji do decyzji ostatecznej (wyczerpaniu

${ }^{10}$ Ustawa z dnia 6 czerwca 1997 r. Kodeks karny. (t.j. Dz. U. z 2016 r. poz. 1137 z późn. zm.). 
drogi odwoławczej przez podmiot gospodarczy) często mija kilka lat. Jednak nawet to nie jest gwarancją skutecznego pozyskania materiału dowodowego w postepowaniu karnym, ponieważ jeśli postepowanie podatkowe zostało przeprowadzone wadliwie może dojść do sytuacji, iż decyzje zostaną uchylone. W takiej sytuacji organy ścigania tracą kluczowy materiał dowodowy (decyzje organu podatkowego). Dlatego już na etapie podejrzenia popełnienia przestępstwa kluczowym jest wyczerpujące zebranie i zabezpieczenie materiału dowodowego, aby uniknać sytuacji, gdy ograny podatkowe, które są pierwszym „ogniwem” zbierającym i zabezpieczającym materiał dowodowy koncentrowały się na wydaniu decyzji na tzw. słupy w ogóle pomijając próbę ustalenia organizatora procederu lub co gorsze wydają decyzje na nieświadomych uczestnictwa $\mathrm{w}$ przestępstwie buforów, a wydane przez nie decyzje jeszcze zostaną uchylone. Jako przykład można powołać tezę Wyroku WSA w Warszawie „Rola podmiotu umiejscowionego $\mathrm{w}$ konstrukcji karuzelowej między znikającym podatnikiem, a brokerem - tzw. bufora jest nieskomplikowana. Jest to podmiot, który skrupulatnie wypełnia wszelkie formalne obowiązki związane $\mathrm{z}$ rozliczeniami VAT, realizując funkcję przewidzianą dla niego przez organizatora oszukańczej praktyki przez samą obecność pomiędzy najbardziej wrażliwymi ogniwami przestępczego łańcucha dostaw. Problem w tym, że obok spółek specjalnie do tego celu utworzonych albo świadomych udziału $\mathrm{w}$ przestępstwie karuzelowym, funkcję tę $\mathrm{z}$ równym powodzeniem spełniać może także uczciwy podatnik, zaangażowany w oszukańczy proceder bez swojej wiedzy i zgody. Stąd też istotne jest w tym zakresie przeprowadzenie szczególnie starannego postępowania dowodowego w celu wykazania przez organy podatkowe, jak doszło do uczestnictwa bufora w karuzeli podatkowej ${ }^{11}$.

Konkludując należy wskazać, iż postępowanie podatkowe może opierać się na „domysłach” organu, że do przestępstwa (wyłudzenia) doszło, gdyż to w zasadzie na podatniku leży ciężar dowodowy, zaś postępowanie karne charakteryzuje się tym, iż to wymiar sprawiedliwości musi ponad wszelką wątpliwość wskazać, iż do przestępstwa (wyłudzenia) doszło w sposób świadomy. Odnosząc to do praktyki jak również do kontroli opublikowanej przez Najwyższą Izbę Kontroli w dokumencie „Przeciwdziałanie wprowadzaniu do obrotu gospodarczego faktur dokumentujących czynności fikcyjne” koniecznym jest zmiana sposobu współpracy między organami podatkowymi, a organami ścigania oraz rozszerzenie tej współpracy o nowe procedury zbierania i zabezpieczenia materiału dowodowego.

\section{Rola biegłych sądowych w postępowaniach dotyczących przestępstw karuzelowych}

Postępowania karne dotyczące przestępnego nadużycia mechanizmów podatkowych należą do jednych z najbardziej skomplikowanych. Mowa zwłaszcza o tych z nich, w których oszukańcze uszczuplenia podatkowe stanowią przestępstwo bazowe dla przestępstwa prania pieniędzy i popełniane są w ramach działalności zorganizowanych grup przestępczych. Nader często sprawy, o których mowa, stanowią przejaw

\footnotetext{
${ }^{11}$ Wyrok Wojewódzkiego Sądu Administracyjnego w Warszawie z dnia 3 lutego 2016 r. III SA/Wa 3473/14 Sytuacja tzw. bufora w mechanizmie oszustwa karuzelowego.
} 
zorganizowanej przestępczości ekonomicznej, w której wykorzystywane są tylko określone mechanizmy podatkowe. Dotyczy to zwłaszcza podatku od towarów i usług oraz akcyzowego. Zachowanie sprawcze jest w ich przypadku wpisane w konstrukcję określonych podatków, które sprawcy wykorzystują do uzyskania nienależnych przysporzeń ze strony Skarbu Państwa. Powoduje to, że stopień komplikacji jurydycznej tych spraw jest bardzo wysoki, wymaga szerokiego odwołania się do wiedzy z zakresu prawa podatkowego, finansów i księgowości. Dotyczy to zwłaszcza etapu postępowania sądowego $\mathrm{z}$ uwagi na brak specjalizacji sądów w rozpoznawaniu spraw karnych gospodarczych. W polskich realiach sądy nie są organizacyjnie przygotowane do prowadzenia takich analiz. Jak bowiem sąd orzekający sam ma zapoznać się z nadesłaną bardzo obszerną dokumentacją, dokonać stosownych wyliczeń i zestawień, wreszcie obliczyć wartości uszczuplonych bądź narażonych na uszczuplenie należności publicznoprawnych, względnie powstałej szkody, bądź też zestawień dotyczących innych kwestii, np. wielkości obrotów ich struktury itp. powołanie biegłego jest wręcz koniecznością $\mathrm{w}$ realiach takiej sprawy. ${ }^{12}$ Jednak w ocenie autora koniecznym jest powołanie biegłego specjalizującego się w przestępczości gospodarczej jak również biegłego z dziedziny informatyki na etapie wszczęcia przez organ ścigania postepowania przygotowawczego. Wynika to $\mathrm{z}$ kluczowego problemu zbierania i zabezpieczania materiału dowodowego, gdzie biegły jest swoistym łącznikiem wiedzy między organem podatkowym specjalizującym się $\mathrm{w}$ prawie podatkowym, a organami ścigania specjalizującymi się w zorganizowanej przestępczości, bowiem biegły specjalizujący się $\mathrm{w}$ przestępczości gospodarczej $\mathrm{w}$ oczywisty sposób łączy prawo podatkowe $\mathrm{z}$ zorganizowanym charakterem przestępczości gospodarczej.

Jak wskazano już w powyższych rozważaniach dla odtworzenia schematu przestępstw karuzelowych, a tym samym wskazania wszystkich uczestników przestępstwa, kluczową rolę odgrywa wyczerpujące zebranie materiału dowodowego. W praktyce organ podatkowy skupia się na jednym lub niewielkiej liczbie uczestników przestępstw karuzelowych, a tymczasem koniecznym jest, aby w celu ograniczenia zjawiska przestępstw polegających na wyłudzaniu VAT dochodziło do identyfikowania wszystkich uczestników karuzeli w tym głównie organizatorów. Pozwoli to na realne ograniczanie skali zjawiska. Aby działania te były możliwe koniecznym jest, aby organy skarbowe i organy ścigania w sprawach o przestępstwa karuzelowe współpracowały $\mathrm{z}$ biegłymi sądowymi. Praktyka pokazuje, iż organy podatkowe w postępowaniach dotyczących przestępstw karuzelowych w ogóle nie współpracują z biegłymi sądowymi. W ocenie autora zaś wspólpraca ta jest kluczowa i pozwoli przyśpieszyć czas prowadzonych postępowań poprzez szybką analizę danych niezbędnych do odtworzenia schematu karuzeli VAT, a w szczególności wszystkich jej uczestników. Organy podatkowe $\mathrm{w}$ prowadzonych postępowaniach skupiają się na wyliczeniu uszczuplenia podatkowego zaś biegły sądowy odtwarza schemat karuzeli VAT ustalając jej uczestników, a dopiero potem po wyłonieniu faktycznych sprawców (uczestników, źródeł kapitałowych i osobowych) przyporządkowuje przestępstwu dane liczbowe wynikające z uszczupleń podatkowych. Biegły jest osobowym źródłem dowodowym

${ }^{12}$ J. Duży: Rozdział I Etiologia zorganizowanej przestępczości nadużywającej mechanizmów podatkowych. W: Zorganizowana przestępczość podatkowa w Polsce. Zwalczanie przestępczego nadużycia mechanizmów podatków VAT i akcyzowego. LEX, 2013, s.134. 
posiadającym wiadomości specjalne. Jego opinia stanowi szczególny samoistny środek dowodowy ${ }^{13}$. Posiada wiadomości specjalne tj. wiedza ekonomiczna poparta doświadczeniem uczestnictwa $\mathrm{w}$ postępowaniach karnych dotyczących przestępstw gospodarczych, czego organy podatkowe w swojej codzienności mają znacznie mniej, a więc biegły stanowi uzupełnienie wiedzy podatkowej i karnej $\mathrm{w}$ przestępstwach gospodarczych zorganizowanych grup przestępczych.

\section{Dodatkowe metody niezbędne w celu ograniczenia zjawiska przestępstw karuzelowych}

Do podstawowych problemów ograniczania przestępstw karuzelowych należy zaliczyć przede wszystkim brak odpowiedniego zebrania i zabezpieczania materiału dowodowego. Dzieje się tak dlatego, iż organy podatkowe na potrzeby wydania decyzji mają inną specyfikę gromadzenia wystarczającego materiału dowodowego niż organy ścigania, którym nie wystarczy już w materiale dowodowym sama decyzja organu podatkowego. Praktyka pokazuje, iż często zebrany materiał dowodowy przez organy podatkowe nie jest wystarczający na gruncie postępowań karnych. W efekcie prowadzi to do swoistej akceptacji, iż w przestępstwach karuzelowych nie dochodzi do wykrycia faktycznych organizatorów, a konsekwencje finansowe i karne są wyciągane najczęściej tylko w odniesieniu do tak zwanych znikający handlowców inaczej zwanych słupami. Aby temu zapobiec konieczna jest zmiana modelu współpracy między organem podatkowym i organami ścigania oraz biegłymi sądowym. W celu efektywnego ograniczania skali przestępstw karuzelowych już od samego prowadzonego postępowania przygotowawczego powinny ze sobą ściśle współpracować. Jeśli chcielibyśmy podejść do sprawy $\mathrm{w}$ pewnym uogólnieniu to wydawało by się, iż wystarczy wprowadzenie procedur zbieranie i zabezpieczenia materiału dowodowego. Jednak $\mathrm{w}$ praktyce nie jest to takie proste, procedury mogą być pewnym elementem uproszczenia jednak musimy pamiętać, iż organy podatkowe nie zbierają materiału dowodowego w sposób wyczerpujący, a organy ścigania po upływie czasu, kiedy sprawa do nich trafia często nawet nie wiedza jaki materiał w tego typu przestępczości poza fakturami należy zabezpieczać. Ponadto w rzeczywistości często nie ma co zabezpieczać, ponieważ przez trwający okres postępowania podatkowego dokumentacja na ogół zostaje przez uczestników procederu zniszczona. Ponadto w przypadku znikających handlowców (słupów) w ogóle nie podejmuje się czynności mających na celu ustalenie skali $\mathrm{i}$ roli $\mathrm{w}$ strukturze przestępstwa karuzelowego, co często jest powielane przez organy ścigania. Niedoceniana jest rola pomocy prawnej międzynarodowej w gromadzeniu wyciagów bankowych znikających handlowców i poddawania ich badaniu przez biegłych sądowych specjalizujących się $\mathrm{w}$ analizach kryminalnych przepływów finansowych zorganizowanych grup przestępczych. Analizy takie są sporządzane przy współpracy biegłych z dziedziny informatyki dysponujących specjalistycznym oprogramowaniem IBM i2 Analyst's Notebook oraz biegłych z dziedziny ekonomii specjalizujących się $w$ analizie zorganizowanych grup przestępczych w zakresie przestępczości gospodarczej. Działania takie nie tylko realnie

${ }^{13}$ T. Tomaszewski: Dowód z opinii biegłego w procesie karnym, Kraków 1998, s. 9. 
skracają czas prowadzonych postepowań zarówno podatkowych jak i karnych, ale przede wszystkim zwiększy to efektywność postępowań, ponieważ na podstawie takiej analizy kryminalnej wspartej wiedzą ekonomiczną z łatwością będzie można wyłonić wszystkich uczestników schematu karuzeli VAT (również znikających handlowców), jak również wskazać osoby faktycznie biorące w niej udział, w tym organizatorów.

Należy pamiętać, że przestępstwa karuzelowe charakteryzują się tym, iż przestępcy dostosowują się bardzo szybko do zmieniającego się otoczenia i zmieniają lub modyfikują stosowane schematy organizacyjne. Dlatego do każdego przestępstwa karuzelowego należy podejść indywidualnie i w chwili nabrania przez organ podatkowy podejrzenia, iż podmiot gospodarczy bierze udział lub jest uczestnikiem karuzeli VAT natychmiast powinny zostać powiadomione organy ścigania, a te włączyć do współpracy biegłego sądowego, który na podstawie już uzyskanego materiału wskaże obszary jaki materiał należy jeszcze zabezpieczyć oraz zidentyfikuje jaki schemat karuzeli w konkretnym przypadku ma miejsce. Pozwoli to znacznie skrócić czas prowadzonych postępowań i będzie miało kluczowy wpływ na prawidłowe zabezpieczenie materiału dowodowego niezbędnego do ustalenia faktycznych sprawców przestępstw karuzelowych. Do katalogu materiału dowodowego, który należy zabezpieczyć od razu z chwilą podejrzenia o popełnionym przestępstwie na pewno można zaliczyć zestaw dokumentacji opisanej w tabeli 1 .

Tabela 1. Dokumentacja podlegająca zabezpieczeniu w postępowaniu karnym w przestępstwach Karuzela VAT

\begin{tabular}{|c|c|c|c|}
\hline Firmy Transportowe & Znikający handlowiec & Bufor & Firma wiodąca \\
\hline $\begin{array}{l}\text { Kopia binarna } \\
\text { ksiegowego programu } \\
\text { hasłami dostęp wraz }\end{array}$ & & $\begin{array}{l}\text { Kopia binarna programu } \\
\text { ksiegowego wraz z hasłami } \\
\text { dostępu }\end{array}$ & $\begin{array}{l}\text { Kopia binarna } \\
\text { programu } \\
\text { ksiegowego wraz } \\
\text { z hasłami dostępu }\end{array}$ \\
\hline $\begin{array}{l}\text { Wyciagi bankowe w wersji } \\
\text { elektronicznej w formacie } \\
\text { PDF lub Excel }\end{array}$ & $\begin{array}{l}\text { Wyciagi bankowe w wersji } \\
\text { elektronicznej w formacie } \\
\text { PDF lub Excel } \\
\text { (uzyskanych również w } \\
\text { ramach międzynarodowej } \\
\text { pomocy prawnej) }\end{array}$ & $\begin{array}{l}\text { Wyciagi bankowe w wersji } \\
\text { elektronicznej w formacie } \\
\text { PDF lub Excel } \\
\text { (uzyskanych również w } \\
\text { ramach międzynarodowej } \\
\text { pomocy prawnej) }\end{array}$ & $\begin{array}{l}\text { Wyciagi bankowe } \\
\mathrm{w} \text { wersji } \\
\text { elektronicznej w } \\
\text { formacie PDF lub } \\
\text { Excel }\end{array}$ \\
\hline \begin{tabular}{lr}
\multicolumn{3}{l}{ Polisy ubezpieczeniowe za } \\
okresy przed & zdarzeniem \\
oraz po & zdarzeniu \\
samochodów & \\
transportujących r towar \\
będący przedmiotem \\
przestępstwa &
\end{tabular} & & $\begin{array}{l}\text { Dokumentacja } \quad \text { źródłowa } \\
\text { faktury sprzedaży zakupu }\end{array}$ & $\begin{array}{l}\text { Dokumentacja } \\
\text { źródłowa faktury } \\
\text { sprzedaży zakupu }\end{array}$ \\
\hline Delegacje kierowców & & $\begin{array}{l}\text { Dokumentacja } \\
\text { magazynowa WZ i PZ }\end{array}$ & $\begin{array}{l}\text { Dokumentacja } \\
\text { magazynowa WZ } \\
\text { i PZ }\end{array}$ \\
\hline $\begin{array}{l}\text { W przypadku } \\
\text { uproszczonej księgowości } \\
\text { tj. Książki Przychodów i }\end{array}$ & & & \\
\hline
\end{tabular}




\begin{tabular}{|l|l|l|l|}
\hline $\begin{array}{l}\text { Rozchodów należy } \\
\text { zabezpieczyć faktury za } \\
\text { paliwo oraz przejazd viatol }\end{array}$ & & & \\
\hline
\end{tabular}

Źródło. Opracowanie własne.

Praktyka pokazuje, iż w sprawach dotyczących zorganizowanych grup przestępczych, działających w obszarze gospodarczym w zasadzie nie występują opinie biegłych z analizy kryminalnej, a biegły sądowy jest powoływany jako „ostatnia deska” ratunku dopiero z chwilą, kiedy sprawa jest bardzo przewlekła i organy nie widzą szans na jej zakończenie. Gromadzenie dokumentacji w aktach sprawy zaś opiera się głównie na wielokrotnym powielaniu kopii faktur. Ponadto znaczenie firm transportowych jest traktowane dosyć marginalnie, a są one kluczowym ogniwem, ponieważ wykazanie, iż transport w rzeczywistości nie miał miejsca odbiera oszustowi podatkowemu prawo do zastosowania zerowej stawki VAT. Dokumentacja opisana w tabeli $1 \mathrm{w}$ znacznym stopniu pozwoli spojrzeć na przestępstwo karuzelowe całościowo i wyodrębnić jej uczestników nawet jeśli dokumentacja zniknie. Organy podatkowe jak również organy ścigania $\mathrm{w}$ ramach międzynarodowej pomocy prawnej korzystają zazwyczaj tylko $\mathrm{z}$ zapytań do organów podatkowych znikających handlowców, które co łatwo przewidzieć odpowiadają, iż firmy nie zastano i np. nie składała deklaracji. W znikomym zaś zakresie korzysta się $\mathrm{z}$ międzynarodowej pomocy prawnej $\mathrm{w}$ zakresie gromadzenia wyciągów bankowych, które pozwolą przeprowadzić kompleksową analizę kryminalną w zakresie uczestnictwa w zorganizowanej grupie przestępczej (karuzeli VAT). Należy też stwierdzić, iż do analizy działalności firm transportowych, a w zasadzie to potwierdzenia czy faktycznie doszło do dostawy wewnątrzwspólnotowej (wywozu towaru) warto dokonać analizy polis ubezpieczeniowych pojazdów przewożących towar, gdyż praktyka pokazuje, że podany przebieg samochodu w polisie po dokonaniu analizy nie pokrywa się z przebiegiem wynikającym z tras zafakturowanych. Często okazuje się, iż ilość wykonanych tras (obliczonych na podstawie faktur wystawionych za transport) nie odpowiada faktycznemu przebiegowi pojazdu wykazanemu na potrzeby polisy ubezpieczeniowej. Narzędzie to jest o tyle istotne, iż w przypadku przestępstw karuzelowych badamy transakcje historyczne, a więc nie ma możliwości zbadania przebiegu pojazdu w czasie rzeczywistym. Niestety procedura ta jest stosowana $\mathrm{w}$ sposób znikomy. Podobnie sytuacja wygląda $\mathrm{z}$ badaniem delegacji kierowców. Zabezpieczenie kopii binarnych pozwala zweryfikować, czy w księgach firmy transportowej w ogóle został zaksięgowany wydatek związany z wyjazdem pracownika (kierowcy). Z uwagi na skomplikowany charakter przestępstw karuzelowych (ich rozległość) zebranie materiału opisanego $\mathrm{w}$ tabeli 1 oraz jego właściwa analiza $\mathrm{w}$ rezultacie prowadzi do ustalenia szeregu czynników potwierdzających udział w karuzeli VAT. Ponadto działania według takiej procedury ograniczą błędy w prowadzonych postępowaniach, w których obecnie zabezpieczenie kopii binarnych już przez organ podatkowy jest $\mathrm{w}$ zasadzie procedurą działającą znikomo, a organy ścigania przestaną gromadzić w aktach sprawy wielokrotne powielanie w formie papierowej faktury. Prowadzone $\mathrm{w}$ ten sposób akta są obszerne, ale nie dają efektywnego zebranego materiału dowodowego, który można podać analizie kryminalnej, a następnie połączeniu jej wyników z analizą danych księgowych znajdujących się na kopiach binarnych programów księgowych. Tak przeprowadzone gromadzenie materiału oraz jego analiza 
pozwala szybciej wyłonić powiązania kapitałowo - osobowe między uczestnikami karuzeli VAT, a finalnie skraca kolosalnie czas wydania opinii oraz zakończenia postępowania.

Reasumując zmiana podejścia zarówno organów podatkowych, które w sposób znikomy w przestępczości zorganizowanej korzystają z biegłych sądowych oraz zmiana podejścia organów ścigania $\mathrm{w}$ gromadzeniu materiału dowodowego oraz powoływaniu biegłych na wcześniejszym etapie postępowania znacznie zwiększy efektywność prowadzonych postępowań i realnie ograniczy przestępczość zorganizowaną w zakresie karuzeli VAT.

\section{Zakończenie}

Konkludując rozważania zawarte $\mathrm{w}$ artykule należy wskazać, iż jedną $\mathrm{z}$ istotnych słabości ograniczania przestępstw karuzelowych jest nieodpowiedni mechanizm zbierania i zabezpieczania materiału dowodowego. Wśród kolejnych słabości należy wskazać, iż organy podatkowe przez specyfikę prowadzonych postepowań (decyzje wydane na znikających handlowców), nie dążą do ustalenia faktycznych organizatorów mechanizmu przestępstwa karuzelowego oraz nie przypisują konkretnych ról jaką pełnią zamieszane podmioty $\mathrm{w}$ przestępstwo (bufor, broker, firma wiodąca, znikający handlowiec). Ponadto w zakresie buforów pełniący tą rolę podmiot deklaruje nieznaczne obroty, terminowo wywiązuje się ze swoich zobowiązań podatkowych oraz wykazuje niewielkie kwoty VAT do zwrotu. Jednak trzeba podkreślić, że bufor może wprawdzie, ale wcale nie musi być świadomym oszustwa popełnionego na wcześniejszym etapie obrotu, czyli tego, że uczestniczy w przestępczej karuzeli. Rolę bufora bowiem obok spółek utworzonych specjalnie do tego celu albo świadomych udziału w przestępstwie karuzelowym pełnić mogą także $\mathrm{z}$ równym powodzeniem uczciwi podatnicy zaangażowani w oszukańczy proceder bez swojej wiedzy i zgody. Taka sytuacja jest zresztą przez organizatorów karuzeli preferowana z uwagi na fakt, że efektywność (z punktu widzenia oczywiście oszustów) danego bufora jest wprost proporcjonalna do siły jego pozycji na rynku oraz stopnia zaufania ze strony organów skarbowych. Dlatego wydana decyzja podatkowa na bufora przez organ podatkowy wcale nie jest potwierdzeniem na etapie postępowania karnego, iż faktycznie brał on udział w przestępstwie. Szczególnie w tym zakresie widać konieczność zmian w podejściu prowadzonych postępowań, które powinny dążyć do wykrywania faktycznych uczestników przestępstwa karuzelowego, a nie „,bezrefleksyjnym” wydawaniu decyzji podatkowych. Kolejnym i w zasadzie ostatnim ogniwem przestępczego łańcucha krajowych dostaw w państwie, do którego towar został sprowadzony przez znikającego handlowca jest tzw. broker. Dokonuje on wewnątrzwspólnotowej dostawy towarów do spółki wiodącej (czyli „kanałowej”) i w ten sposób obieg karuzeli się zamyka. Mówiąc inaczej, broker dokona odsprzedaży nabytych towarów do tego samego państwa, z którego towary te zostały wcześniej sprowadzone przez znikającego handlowca. Praktyka pokazuje, iż organy podatkowe nie zamykają w postępowaniach tzw. obiegu karuzeli, a organy ścigania przy nieodpowiednim zebraniu materiału dowodowego mają to zadanie znacznie utrudnione. Stąd mówi się o dużej bezkarności organizatorów karuzeli oraz przewlekłości postępowań. Należy zauważyć, iż broker wypełnia bez zarzutu wszelkie obowiązki nałożone przez lokalne przepisy z zakresu VAT, niemniej 
jednak każdy wniosek o bezpośredni zwrot VAT będzie najczęściej skutkował kontrolą badająca jego zasadność. W czasie tego typu działań weryfikacyjnych niejednokrotnie przedmiotem zainteresowania inspektorów skarbowych staną się rozliczenia z zakresu VAT-u dostawców brokera (np. poprzez znany z polskich regulacji prawnych mechanizm tzw. kontroli krzyżowych). W tym miejscu uwidacznia się więc $\mathrm{w}$ pełni znaczenie, jakie dla powodzenia całego schematu karuzelowego ma odpowiednia sieć buforów. Organy skarbowe mogą niejednokrotnie natrafić na długi łańcuch dostaw, zakończonych sprzedażą na rzecz brokera, który nie budzi żadnych zastrzeżeń z punktu widzenia prawidłowości rozliczeń VAT-u. W konsekwencji zidentyfikowanie brakującego ogniwa w łańcuchu transakcyjnym i brakującego podatku należnego nie jest najczęściej możliwe w ramach analizy zasadności podstaw zwrotu różnicy VAT na rzecz brokera. Niejednokrotnie badany przed ponownym wprowadzeniem towaru do karuzeli, czyli do spółki wiodącej, dokonuje eksportu do krajów trzecich, czyli poza Unię Europejska. Jest to bardzo skuteczna metoda zatarcia śladów przestępstwa poprzez utworzenie luki w łańcuchu dostaw wewnątrz Unii Europejskiej, którego analiza jest obecnie podstawowa metoda operacyjną nakierowana na wykrycie tego typu zorganizowanych oszustw. Przedstawiony mechanizm karuzelowy opiera się więc na tym, że organy skarbowe, którym udaje się wprawdzie wykryć strukturę karuzelową poprzez identyfikacje brakującego ogniwa (tj. brakującego podatku należnego) w łańcuchu dostaw natrafiają na poważny problem zrekompensowania poniesionych przez sektor publiczny strat finansowych. $Z$ jednej bowiem strony brak jest jakiegokolwiek majątku po stronie „znikającego handlowca” (gdyż on sam zniknął, a nielegalnie osiagnięte zyski zostały wytransferowane), z drugiej zaś strony prawidłowość rozliczeń pozostałych podatników biorących udział $\mathrm{w}$ karuzeli jest bardzo trudna do zakwestionowania. Zresztą - jak wspomniano, podmioty te nie musza być nawet świadome, że uczestniczą w przestępstwie ${ }^{14}$. Dlatego kluczową rolę odgrywa odpowiednie zbieranie i zabezpieczanie materiału dowodowego już na początku postępowania podatkowego oraz korzystanie ze specjalistycznych analiz kryminalnych przepływów finansowych zorganizowanych grup przesteppczych. Analizy takie są sporządzane przy współpracy biegłych $\mathrm{z}$ dziedziny informatyki dysponujących specjalistycznym oprogramowaniem IBM i2 Analyst's Notebook oraz biegłych z dziedziny ekonomii specjalizujących się $\mathrm{w}$ analizie zorganizowanych grup przestępczych w zakresie przestępczości gospodarczej.

Praktyka pokazuje, iż organy podatkowe skupiają się najbardziej na analizie faktur zakupu i sprzedaży, zatrudnieniu ludzi, posiadanym zapleczu technicznym przez przedsiębiorstwo np. magazynach natomiast $\mathrm{w}$ węższym zakresie skupiają się na szczegółowej analizie firm transportowych oraz przepływów pieniężnych. To właśnie analiza przepływów pieniężnych pozwala często ustalić cały przebieg schematu i udowodnić kto był organizatorem karuzeli $\mathrm{i}$ do kogo faktycznie towar wrócił. Reasumując koniecznym jest zaciśnięcie współpracy między organami podatkowymi, które niezwłocznie powinny organy ścigania zawiadamiać o możliwości

${ }^{14}$ L. Wilk: Kryminalne aspekty przestępczości podatkowej, Archiwum Kryminologii, TOM XXXI/2009, Warszawa 2009, s. 214-216. 
popełnienia przestępstwa karuzelowego, a organy ścigania, które jak praktyka pokazuje opierają zbieranie materiału dowodowego głównie na organach podatkowych. Jak już wykazano w tym artykule jest to nieskutecznym narzędziem, powinny one wprowadzić procedurę zbierania i zabezpieczania materiału już na samym początku podejrzenia popełnienia przestępstwa, a wśród tych procedur powinna być ścisła współpraca między biegłym sądowym, który poprzez swoje doświadczenie w sprawach karnych dotyczących przestępstw podatkowych będzie w stanie wskazać obszary, w których możliwe jest zebranie materiału dowodowego, a który to materiał pozwoli na odtworzenie schematu zastosowanego podczas przestępstwa karuzelowego w konkretnym przypadku. Praktyka niestety pokazuje, iż organy ścigania dopiero po trzech do sześciu lat od momentu wszczęcia postępowania zwracają się do biegłego sądowego o analizę zebranego materiału i wskazanie faktycznych sprawców przestępstw podatkowych co z uwagi na upływ czasu prowadzi często do tego, że zebranie materiału dowodowego jest niemożliwe, ponieważ dokumentacja albo uległa przedawnieniu albo została zniszczona. Organy podatkowe przez zabezpieczenie dokumentacji w znikomym zakresie korzystaja z biegłych $\mathrm{z}$ dziedziny informatyki razem z biegłymi z dziedziny księgowości, którzy w praktyce używając programów komputerowych księgowych są w stanie na miejscu w podmiocie wyodrębnić dane i zabezpieczyć materiał niezbędny do zweryfikowania czy doszło do popełnionego przestępstwa.

Wyniki przeprowadzonych rozważań wskazuja, iż koniecznym jest rekomendowanie stworzenia procedur $\mathrm{w}$ zakresie zbierania i zabezpieczania materiału dowodowego, który faktycznie jest przydatny w efektywnie prowadzonych postępowaniach zarówno podatkowych, jak i karnych, co pozwoli na wyłonienie faktycznych organizatorów przestępstwa. Konieczna jest również bardziej intensywna współpraca między organami podatkowymi, organami ścigania oraz biegłymi sądowymi z dziedziny informatyki i ekonomii, która w realny sposób pozwoli ograniczyć proceder stosowanych mechanizmów karuzeli VAT.

\section{Bibliografia}

Duży J.: Rozdział I Etiologia zorganizowanej przestępczości nadużywającej mechanizmów podatkowych. W: Zorganizowana przestępczość podatkowa w Polsce. Zwalczanie przestępczego nadużycia mechanizmów podatków VAT i akcyzowego. LEX, 2013

Raport NIK. Informację o wynikach kontroli, Przeciwdziałanie wprowadzaniu do obrotu gospodarczego faktur dokumentujących czynności fikcyjne, Nr ewid. 24/2016/P/15/011/KBF, NIK, Warszawa 2016

Kancelaria Prezesa Rady Ministrów. Materiały szkoleniowe $\mathrm{z}$ tematu pn. Transakcje wewnątrzwspólnotowe ze szczególnym uwzględnieniem transakcji trójstronnych i łańcuchowych oraz identyfikacja oszustw karuzelowych w handlu wewnątrzwspólnotowym. Warszawa.

Matusiakiewicz $Ł$. Zastosowanie dowodów z innych postępowań w postępowaniu podatkowym [online]. Publikacje Elektroniczne ABC, Dostępny w Internecie: https://sip.lex.pl/\#/publikacja/469884042.

Postanowienie Trybunału Sprawiedliwości z dnia 6 lutego 2014 r. C-33/13, Prawo do odliczenia w przypadku faktury wystawionej przez spółkę działająca jako firmant.

Rozporządzenie Komisji (WE) nr 1925/2004 z dnia 29 października 2004 r. ustanawiające szczegółowe zasady wykonywania niektórych przepisów rozporządzenia Rady (WE) nr 1798/2003 w sprawie współpracy administracyjnej w dziedzinie podatku od wartości dodanej (Dz. U. UE. L. z 2004 r. Nr 331, str. 13 z późn. zm.). 
Tomaszewski T.: Dowód z opinii biegłego w procesie karnym, Kraków 1998

Ustawa z dnia 11 marca 2004 r. o podatku od towarów i usług (t.j. Dz. U. z 2016 r. poz. 710 z

późn. zm.).

Ustawa z dnia 6 czerwca 1997 r. Kodeks karny. (t.j. Dz. U. z 2016 r. poz. 1137 z późn. zm.).

Wilk L.: Kryminalne aspekty przestępczości podatkowej, Archiwum Kryminologii, TOM

XXXI/2009, Warszawa 2009

Wyrok Wojewódzkiego Sądu Administracyjnego w Warszawie z dnia 3 lutego 2016 r. III SA/Wa

3473/14 Sytuacja tzw. bufora w mechanizmie oszustwa karuzelowego.

\section{Summary}

One of the mechanisms that significantly contributes to the existence of VAT gaps, is a tax fraud within the so-called tax carousel. The idea of the carousel is based on the characteristic of the current VAT system, namely, on the principle that the VAT due is paid into accounts of the tax office by the seller of the goods. At the same time, however, the purchaser, being an active VAT taxpayer has the right to exercise of the right to deduct the so-called input VAT. If the sum of input VAT from goods and services exceeds the amount of output VAT on sales made by the taxpayer in the relevant accounting period, a taxpayer is entitled to receive direct VAT refund. It is the VAT refund which is a prerogative for tax criminals to open up a number of business entities and create a mechanism of tax carousels to obtain financial benefits from unduly received VAT refunds. Unfortunately, the scale of this phenomenon shows that both the tax authorities as well as law enforcement agencies do not cope with limiting this scale. The aim of the article is to identify new ways of reducing carousel offenses, which in cooperation with tax authorities, law enforcement agencies and expert witnesses will significantly reduce the scale of this phenomenon. The added value of the study is that new methods do not require legislative changes, thus they can be immediately applied in practice. In order to present the aims, methods of research were used based on the analysis of domestic and foreign publications as well as public data provided by the Ministry of Finance and the legal acts in force. The considerations discussed in the article are both theoretical and practical.

Key words: tax evasion, tax audits, preventing tax evasion, vat carousel, expert witnesses' opinions.

\section{Informacja o autorze:}

\section{mgr Sonia Kozub - Skalska}

Uniwersytet Ekonomiczny w Katowicach

Wydział Finansów i Ubezpieczeń

Katedra Finansów Przedsiębiorstw i Ubezpieczeń Gospodarczych

e-mail: sonia.kozub.skalska@edu.uekat.pl 